This item was submitted to Loughborough's Research Repository by the author.

Items in Figshare are protected by copyright, with all rights reserved, unless otherwise indicated.

\title{
Territorial attachment in the age of globalization: the case of Western Europe
}

\section{PLEASE CITE THE PUBLISHED VERSION}

http://dx.doi.org/10.1177/0969776412445830

\section{PUBLISHER}

Sage (@ the authors)

\section{VERSION}

AM (Accepted Manuscript)

\section{PUBLISHER STATEMENT}

This work is made available according to the conditions of the Creative Commons Attribution-NonCommercialNoDerivatives 4.0 International (CC BY-NC-ND 4.0) licence. Full details of this licence are available at: https://creativecommons.org/licenses/by-nc-nd/4.0/

\section{LICENCE}

CC BY-NC-ND 4.0

\section{REPOSITORY RECORD}

Antonsich, Marco, and Edward C. Holland. 2019. "Territorial Attachment in the Age of Globalization: The Case of Western Europe". figshare. https://hdl.handle.net/2134/16108. 


\title{
Territorial attachment in the age of globalization - the case of Western Europe
}

\begin{abstract}
The age of globalization has often been associated with de-/re-territorialisation processes. The increasing integration of markets and the appearance of new modes of economic production and capital accumulation, on the one hand, and the transformation of forms of political governance, on the other hand, have both led to the emergence of new territorial actors at the supra-national and sub-national scales. While these economic and political de-/re-territorialisation processes have been studied at length, relatively little attention has been paid to the transformation of the territorial identities associated with these spaces. The aim of the present study is twofold. First, it aims to understand whether territorial identities are experiencing a similar re-scaling along with modes of economic production and forms of political governance. Second, it explores which factors today explain the attachment of people to their territories. A descriptive analysis of Eurobarometer survey data for Western Europe reveals no signs of a re-scaling of territorial identities, pointing to a sort of inertia of these identities in relation to the changing of political and economic structures. A statistical model on four scales of territorial attachment (local, regional, national, and European) shows the complexity of its formation, as both personal compositional and regional contextual factors should be taken into account.
\end{abstract}

Key words: attachment, identity, Western Europe, regional, local, national, European 


\section{Introduction}

The relationship between territory and collective identity in the age of globalization is a complex one. Since the early 1990s, a growing literature has questioned the persistence of the nation-state as an effective economic and territorial unit for ensuring the welfare of its inhabitants (O'Brien, 1992; Ohmae, 1993; Badie, 1995; Guéhenno, 1995). The accelerated circulation of people, commodities, capital, information, and images has supposedly undermined the role and power of the nation-state (Jessop, 1993; Amin and Thrift, 1995; Hirst and Thompson, 1995; Swyngedouw, 1997; Keating, 1998; Brenner, 1999; Castells, 2000; Jones, 2001; Le Galès, 2002). At the same time, newly empowered territorial units (cities, regions, and supra-national institutions) have emerged as significant actors in the functioning of the global economy, questioning, directly or indirectly, the role of the nation-state as the sole container of territorial identities (Taylor, 2000; Sassen, 2006; Paasi, 2009; Keating, 2009).

This process of re-scaling, defined here as the shifting of a variety of processes away from their traditional level of aggregation, has largely been studied in terms of the transformation of modes of economic production and forms of political governance. Yet, whether this process of re-scaling also influences the ways people express their collective identities is something which has only partially been investigated (Mlinar, 1992; Scholte, 1996; Yaeger, 1996; Castells, 1997; Agnew, 1999; Berezin and Schain, 2003; Croucher, 2004; Savage et al., 2004; Fitjar, 2010). In other words, is the re-scaling of political and economic processes accompanied by a similar rescaling of territorial identities?

The purpose of this article is to offer a quantitative analysis of territorial identities in the present globalized era, focusing both on the question above and on the fac- 
tors which today explain territorial identities. Operatively, the study analyzes Eurobarometer survey data for territorial attachment covering the original fifteen memberstates of the European Union (EU-15) - a geographical area which encompasses almost all of Western Europe. The explicit assumption we make is that, at least in quantitative terms, territorial attachment can be used as a proxy to study territorial identities. Although this operationalization is unavoidable, as Eurobarometer does not have a question about 'identity' per se, we would argue that attachment and identity are often viewed in the literature as closely related or used interchangeably (Low and Altman 1992; Williams et al. 1992; Twigger-Ross and Uzzell 1996; Lewicka 2008). Moreover, looking at the praxis adopted in other survey studies concerned with territorial identities, these latter are also operationalized in alternative terms - for instance as 'belonging' (European Values Study) or as a feeling of 'closeness' (International Social Survey Programme).

The article is divided into three parts. The first part reviews the literature on the interaction between place and identity, as theorized by scholars working in humanistic geography and environmental psychology, which in turn serves as the basis for interpreting the formation and consolidation of territorial attachments. In section two, we examine the series of Eurobarometer survey data (1991-2007) for territorial attachment at four scales (local, regional, national and European), to answer the 're-scaling' question. The third part analyzes statistically the same four scales in order to understand the predictors of territorial attachment, testing the significance of a set of controls and geographically defined contextual variables included in the statistical model. A concluding section summarizes the key findings and briefly suggests avenues for further work on the topic. 


\section{Geography, place and the making of territorial attachment}

In her voluminous study of the imbrications of territory, authority and rights, Sassen (2006) points to the link between territorial identities, political institutions and economic modes of production. Since its emergence in the $18^{\mathrm{h}}$ century, as a technical device of the European monarchical states to standardize, homogenize and disciplinize social and material reality (Alliès, 1980), territory has been theorized in close connection with the 'political' and the 'cultural' - a perspective which continues to inform scholarly attempts to investigate the restructuring of contemporary territorialities (Ansell and Di Palma, 2004; Antonsich, 2009).

Departing from these theoretical premises, it is legitimate to analyze whether the re-scaling associated with the shift from a Fordist economy, based on mass production and consumption organized at the national scale, to the present post-Fordist economy, characterized by local flexible production working within an inter-dependent market organized at the global scale (Jessop, 1994), is also associated with a shift in territorial attachment and identity. To be sure, the 're-scaling' of modes of economic production is not just a new name to capture an old phenomenon. The de-nationalization process experienced by present economies is not only a historical shift in the forms of capital (re)production and accumulation (Brenner, 1999), but also a feature of contemporary forms of political governance, with new actors claiming spaces of political action which once belonged exclusively to the state (Keating, 1998; Le Galès, 2002).

Numerous scholars, working in both geography and environmental psychology (see, for example, Antonsich, 2010a and Hidalgo and Hernandez, 2001 respectively), have used 'place attachment,' or the related 'sense of place,' as key organizing concepts to understand how individuals relate to a given geographical space. While the strength of an 'affective bond' between people and places is widely agreed upon - the 
significance of a particular place is determined by a human's ability to ascribe meaning to that place (Tuan, 1976)—place itself remains an abstract concept.

Agnew's (1989: 9) proposal for a 'concept of place in which spatially extensive fields of economic and political power are mediated through historically defined conjunctures of social interaction specific to localities' moves towards a more grounded conceptualization. Taking this idea further, Agnew $(1987 ; 1996)$ emphasises the notion of geographic context in order to investigate how geographic location and locale potentially influence political opinion and collective perceptions. Though we do not equate place and territory, the latter, defined here as a "politico-institutional bounded space' (Antonsich 2009: 789), is an environment—like place—-that influences a variety of individual and collective opinions. In turn, if territory is understood, following Elden (2010: 811), as 'a political technology,' it might also become something that the individuals sited within it identify with and are attached to. As a 'political technology,' territory can indeed supplement an emotional connection through the provision of services (i.e. education) or by operating as economic containers for growth (Taylor, 1994), among other examples. While the 'territorial' has an historical basis, we are interested here in contemporary manifestations of attachment to territory in some of its actual forms: the local, the regional, the national, and the European. Territories, therefore, at different scales, can be both the contexts which shape people's feeling of attachment and the source of attachment itself.

Unlike the related concept of place attachment, territorial attachment has been both under-theorised and infrequently subjected to empirical analysis (see Marks, 1999 for an exception). In part, the present article is a first attempt at addressing these shortcomings in the wider literature. Identity is not absolute, and individuals can simultaneously maintain loyalties and attachments to different territorial aggregates (Herb 
and Kaplan, 1999). As also observed by Marks (1999: 87), individuals may indeed have mutually inclusive territorial identities. Marks, against whose empirical work we partly position our analysis, leaves a set of important points unaddressed: how identities are mobilized in different locales, and the alternative characteristics that affect territorial attachment among individuals. Before moving to these questions, we first want to analyze the relevance of territorial identities and, more specifically, understand whether in a context of increased globalization processes territorial identities have somewhat experienced any type of re-scaling. Our attempt to understand what motivates territorial attachment considers both individual characteristics and contextual variables variously affected by territorialized space.

\section{The empirics of territorial attachment}

Our choice to focus on Western Europe has both theoretical and practical justifications. Theoretically, because of the high exposure to globalization processes (i.e., the internationalization of markets, the international mobility of people and goods, technological innovation, communication flows, etc.), this region is a relevant case study to test the hypothesis of the 're-scaling' of territorial identity in the post-Fordist era. Practically, the Eurobarometer Standard Survey lacks an adequate time series on territorial attachment for Europe as a whole. ${ }^{1}$

The present study focuses on Eurobarometer data collected in response to the following question: "People may feel different degrees of attachment to their town or village, to their region, to their country, or to Europe. Please tell me how attached you feel to...?". Respondents answered the question on the basis of a four-point Likert-type scale: "very attached;" "fairly attached;" "not very attached;" and "not at all attached." This question has been asked periodically since 1991, though a slightly dif- 
ferent wording has been used in some rounds. ${ }^{2}$ Figure 1 shows the cumulative trend ("very attached" + "fairly attached") for the four levels of territorial attachment, aggregated across the EU-15 states. $^{3}$

\section{INSERT FIGURE 1 APPROXIMATELY HERE}

Apart from European attachment, which displays an inconsistent pattern across surveys, the other three forms of attachment have been generally stable for the last two decades. This suggests that the re-scaling of the political and economic functions of the nation-state has not been accompanied by a similar rescaling of territorial identities as measured in terms of territorial attachment. This finding somewhat challenges the widespread assumption that globalization is associated, among others, with an increase of local or regional identities.

Overall, but not by a large margin, the national remains the principal form of identification for respondents. In 2007, $91 \%$ of respondents affirmed to be either "very" (55\%) or "fairly" (36\%) attached to their own country. This result is consistent with the findings of the 1991 survey, when $90 \%$ of respondents answered that they were "very" (58\%) or "fairly" (32\%) attached to their own nation. One can therefore infer that either national identity, as operationalized through attachment, is not affected by the changing politico-economic conditions associated with globalization and the post-Fordist economy, or such identification is inelastic, with the logic of social identification responding only gradually to changes in political-economic structures (Poche, 1992).

Similar considerations apply to local and regional attachments. Interestingly, the two overlap across surveys, thus suggesting that people might tend to look at their lo- 
cality and their region in similar ways - a finding also confirmed by a recent qualitative study (Antonsich, 2010b). In the case of European attachment, variation across surveys is clear. Apart from a major downturn registered in 2002 - the year the Euro entered circulation-attachment to Europe is increasing. In 2007, 67\% of people interviewed responded that they were either "very" (22\%) or "fairly" (45\%) attached to Europe-an increase of $19 \%$ compared to the 1991 survey, when overall $48 \%$ of respondents declared to be either "very" (12\%) or "fairly" (36\%) attached. To some extent, these figures support the argument that a sense of Europeanness can be generated a posteriori by the process of European integration itself, rather than being a necessary, pre-existing condition for integration (Kohli 2000, Gabel 1998a). Whether such a feeling, though, can endure periods of serious stress, like the ones associated with the Union's eastern enlargement (in 2004 and 2007) or the present 'Euro crisis', is an issue which cannot be addressed within the space limitation of this article.

Here we would like instead to highlight the positive correlation among territorial identities. Table 1 shows correlation coefficients (Kendall tau-b) for local, regional, national, and European attachment for individual respondents using two Eurobarometer data sets, fielded respectively in 1995 (EB 43.1bis) and in 2007 (EB 67.1) (see Table 1$)^{4}$

\section{INSERT TABLE 1 APPROXIMATELY HERE}

Territorial identities at different scales are positively correlated for individualssomething which has been suggested in previous studies (Duchesne and Frognier, 1995; Marks, 1999; Opp, 2005). ${ }^{5}$ Attachment is not mutually exclusive, though correlation is stronger across "neighbouring" scales - the local and regional being more correlated than the local and national, for example. The table also shows longitudinal 
change, as the tau coefficients increase from 1995 to 2007 for all comparisons. This suggests that territorial attachment is blended to a greater extent than in the mid1990s. Respondents in 2007 were more likely to feel simultaneously attached to the regional and European scales. In other words, territorial identities tend to be more closely knitted today than fifteen years ago; in the age of globalization, the relationship between forms of territorial identity has strengthened.

One important caveat applies to the present analysis-could the territorial rescaling have taken place before 1991? Rokkan and Urwin (1983: 118), for instance, talk of a revival of regionalist movements already back in the 1960s-1970s. In order to address this potential issue we considered a different data set, the European Values Study, which since 1981 has periodically asked, among others, the two following questions: "To which of these geographical groups would you say you belong to first of all? Locality or town where you live; Region or country where you live; Your country as a whole; [Continent]; The world as a whole"; "And next? [same options]".

\section{INSERT FIGURE 2 APPROXIMATELY HERE}

Figure 2 shows the longitudinal cumulative (first and second choices) levels of geographical belonging, aggregated across six Western European countries. ${ }^{6}$ The absolute values for each geographical units offer somewhat a different picture from the one observed in the EB surveys. This can be due, among others, to the limited number of countries and/or to the different geographical units included in the EVS survey. Here, though, we are not concerned with a comparison of the two surveys, but with the time under investigation. Apart from the years 1999-2000, when regional and country belongings experienced a remarkable change (a change which, surprisingly, 
goes in the opposite direction from the one detected in the EB surveys for the same years), Figure 2 does not reveal any re-scaling of territorial identities even for the longer period under consideration - 1981-2008. Available survey data do not allow for an earlier analysis. ${ }^{7}$ Yet, even if an increase of regional identities happened in the 1960s-1970s, it would be unlikely to be caused by globalization processes as defined above, since these processes had not yet fully manifested in those years.

\section{The determinants of territorial attachment}

The above results are interesting, if somewhat expected. Despite the re-scaling of modes of economic production and forms of political governance, respondents in the Eurobarometer surveys indicate stable levels of high attachment to traditional 'socio-spatial containers': the local, regional, and national. This review provides little insight, however, into the determinants of such territorial attachment, a shortfall that leaves a range of questions unanswered. In order to explore what factors account for attachment across the four territorial scales, we have merged a specific Eurobarometer data set (EB 60.1, 2003) with Eurostat data concerning the socio-demographic features of the regions where individuals were surveyed. ${ }^{8}$ This multi-level approach was employed to evaluate the relevance of both individual characteristics and geographical context in influencing strength of territorial attachment. Since very few studies (Marks, 1999; Díez Medrano and Gutiérrez, 2001; Opp, 2005) have so far investigated territorial identities at multiple scales, our analysis is largely explorative.

The inclusion of the Eurostat variables was motivated by theoretical considerations, but had to be positioned against restrictions resulting from the limited amount of data available. Given the theoretical interests of the paper-the impact of globalization on territorial identity and attachment-we incorporated variables that ad- 
dressed the economic structure of the region, its welfare, its economic performance, its rural/urban character, and the levels of unemployment of the region's inhabitants. The implicit rationale driving this selection was the assumption that economic factors are usually significant in explaining social attitudes. Practically, however, Eurostat data presented some limitations in terms of both time and geographical coverage. Reaching a compromise between theory and practicality, the following contextual indicators were chosen: GDP per capita (in Purchasing Power Parity); GDP growth; unemployment rate; employment in technology and knowledge-intensive sectors; and population density. The contextual variables - all measured at NUTS 2 level $^{9}$ —are defined as follows:

- GDP per capita (PPP): Gross domestic product (GDP) at current market prices measured in Purchasing Power Parities (PPP) per inhabitant.

- GDP growth: real growth rate of regional GDP at market prices measured as a percent change on previous year.

- Unemployment rate: unemployed persons as a percent of the total workforce.

- Employment in high-tech sectors: employed persons in technology and knowledge-intensive sectors as a percent of total employment. This variable aims to capture the degree of exposure of the region to the global economy.

- Population density: defined as inhabitants per square kilometre, population density is an indicator which aims to capture the urban/rural character of the regions under scrutiny.

In order to take into consideration the variance of these indicators over time, the mean values for the years 2001-2003 were used instead of the 2003 data-with the exception of data for population density; for a number of regions, data was not available for the year $2001 .^{10}$ By averaging the data longitudinally, we addressed the theo- 
retical concern (see, for example, Tunstall et al., 2000) that people's behaviour is dependent more on the perception of a change (e.g., the perception that this year my income has decreased in relation to last year) than on their actual living condition (e.g., how much money I have right now).

These regional-scale variables were complemented by demographic and compositional controls drawn from the Eurobarometer dataset, including:

- Geo-demographic categories: gender, age, education, employment status and the geographic character of a respondent's place of residence—rural, small, or large town (coded continuously).

- Personal values and attitudes of the respondents: personal expectation about one's life (coded continuously, with $1=$ worse, $2=$ same and $3=$ better); near-term expectation about the economic situation of the country of residence (coded in the same order as personal expectation); importance of family in day-to-day life (coded as a dummy variable, with $1=$ important); willingness to learn a foreign language ( 1 =willing, $0=$ not willing); national pride (coded as a dummy variable, with $1=$ fairly or very proud); European pride (coded in the same fashion as national pride); political preference (categorized continuously as right, centre, and left); and political interest (how often a respondents speaks with her/his friends about politics; continuously coded from $1=$ never to $3=$ frequently).

The justification for including this last set of controls was based on prior statistical studies on European attachment and identity. This work has found that oftentimes individuals' answers are dependent more on subjective perceptions about reality than on objective economic indicators (Gabel and Whitten, 1997; Carey, 2002). Moreover, following the work by Inglehart $(1970 ; 1977)$ on the importance of cognitive mobilization for explaining support for the EU, we included a variable that measures the de- 
gree to which an individual discusses political issues in a non-professional setting (see also Carey, 2002). ${ }^{11}$

\section{Modelling}

In the analysis, structuring the dependent variable was complicated by the fact that responses for territorial attachment were collected on a four-point Likert-type scale, as introduced above. We initially ran an ordinal regression; this is an appropriate model choice when the data are clearly ordered. However, the critical assumption of this model, that the effect of the independent variables is the same for each level of the dependent variable, was violated. In fact, the "test of parallel lines" turned out to be significant for any link function used (probit, logit, or complementary log-log). Therefore, the dependent variable was recoded as a binomial variable (1='very'+'fairly attached'; $0=$ 'not very'+'not at all attached') and we ran a binary logistic regression.

Logistic regression is used to estimate the odds of a certain event, more precisely defined as the probability an event occurs divided by the probability of the corresponding non-event, when the dependent variable is coded binomially. Moreover, logistic regression does not require that the dependent variable be normally distributed; untransformed, territorial attachment at the local, regional and national scale is not normally distributed. There are some drawbacks to this model; dichotomizing an ordinal variable results in a loss of information, which can only slightly be compensated by the fact that the new statistical model offers an easier way to interpret the coefficients (Pampel, 2000). A clearer understanding of what motivates attachment to the four scales under consideration is the central aim of this paper; this is made easier through the transformation of the dependent variable into a binary measure. There- 
fore, we view the compromise between coefficient interpretation and loss of explanatory power as acceptable.

Since answers for territorial attachment were collected separately for the local, regional, national and European, four models were generated, one for each scale of attachment. The analysis included two steps. For each of the four scales, we first evaluated each of the variables separately. After each of the variables selected was considered, we then ran the fully specified model. The results of this modelling are provided in Appendix 1. A number of interesting patterns emerge from the models that we discuss below. Rather than parsing out this summary to each of the four scales considered, each is discussed simultaneously, with an emphasis on the results of the final, fully specified model. Due to space considerations, we focus our discussion only on those predictors that were significant in this final iteration.

\section{Results}

In the first set of controls, which included the geographic and demographic measures associated with individual respondents, age is the most consistently significant explanatory factor. A one-category increase in age-respondents were grouped into six age classes-leads to an associated increase in attachment at all four territorial scales. Age is significant across all four final models, though the results for attachment to the national scale are most notable; an incremental increase in the age category is associated with a fifteen percent rise in attachment. This suggests that young respondents are significantly less likely to feel attached to the territories considered in comparison to older generations. Importantly, this result challenges the pre-existing literature that suggests a negative relationship between age and European identity and support (Janssen, 1991; Gabel, 1998b). Younger respondents are less likely to indicate 
attachment across all four scales, showing a sort of indifference to traditional political territories/boundaries, Europe included. It might also be that young people have a more cosmopolitan view of the world that even the idea of Europe fails to capture, or that inclusion in the geographic contexts considered increases as individuals age (see Schueth and O'Loughlin, 2008). ${ }^{12}$

With respect to gender, males are significantly less likely to indicate attachment to the national territory. The results for the other scales are inconclusive; as such, we are unable to confirm the "gender gap" reported in other studies (Nelsen and Guth, 2000), which find that women report lower levels of support for a pan-European political project in comparison to men.

Education plays an ambiguous role in estimating attachment across the four scales, although this uncertainly mirrors what other authors have observed in the case of support for the European Union (Inglehart, 1977; Janssen, 1991; Deflem and Pampel, 1996; Gabel, 1998a; Carey, 2002). With regard to local, regional and national scales, as education increases, reported attachment decreases; these results are significantly at the 0.001 level for the local and the regional, and to the 0.01 level for the national. The opposite is generally true for European attachment, though the variable is not significant in the final model. Employment status and the rural/urban character of the place of residence of respondents generally have little effect on territorial attachment; only in the case of attachment to Europe are those currently not working significantly more likely to indicate attachment.

Among the controls which measure personal values and attitudes, the importance given to family proved significant in all the four models; those who identified the family as an important component of their life were significantly more likely (at the 0.001 level) to indicate attachment to each of the four scales. This might mean 
that people who espouse traditional values - as represented by the importance given to family-are more likely to feel attached to territory (at any scale, Europe included) than others. Attachment to the region and nation is associated with the highest likelihood, with respondents roughly 50 percent more likely to indicate attachment.

Willingness to learn foreign languages is also significant in three of the four models, being inversely associated with local, regional, and national attachment, but directly related to European attachment (it is not significant for national attachment). This confirms the original expectation; people who want to learn a foreign language are more 'open' than others and as such their likelihood to feel attached to traditional 'containers' (locality, region, and nation-state) is lower than others. The likelihood of attachment to Europe is higher for those interested in learning a foreign language in comparison to the remainder of the population.

Individual expectations as associated with a respondent's personal life are only significant in the model evaluating local attachment; those who expect a worsening of their situation are more likely to indicate attachment to their locality. The independent variable measuring expectations regarding the economy of the country in which one lives is significant for the local and European scales; those with a positive economic outlook are, interestingly, more likely to indicate attachment to the locality and the European Union. A "feeling good" factor is therefore an important dimension to explain territorial attachment. The variable for political interest confirms Inglehart's cognitive theory, which argues that higher level of cognitive mobilization (as here epitomized by the degree to which a person talks of political issues) leads to a higher cosmopolitan attitude and therefore a more positive attitude towards Europe.

National pride and European pride both play important roles in explaining territorial attachment. Though the close relationship between pride and attachment to the 
nation and Europe is unsurprising, the inclusion of the pride variables results in notable outcomes for attachment to the more parochial scales. People who are either very or fairly proud of their nation are significantly more likely (at the 0.001 level) to feel an attachment to their locality and region, by a factor of 2.5. For European attachment, and in support of the findings of Carey (2002), individuals with higher reported national pride are significantly less likely to report attachment to Europe. Interestingly, when attachment is evaluated with respect to European pride, those respondents who are either very or fairly proud of being European are significantly more likely to indicate attachment to the region, nation, and Europe. This result seems to suggest that while the nation tends to be a more exclusive identifier, Europe stands instead for a more open identity marker, capable of coexisting with other identity dimensions more than the nation.

In the final models, the self-ascribed position on the political spectrum (right, centre, left) does not play a significant role in explaining territorial attachment. This result was not expected in relation to European attachment, since previous studies (Inglehart et al. 1991; Franklin et al. 1994; Gabel 1998b) have demonstrated the importance of political partisanship. Upon deeper reflection, this ambivalence is explainable by the fact that different political parties, occupying different positions on the political spectrum, voice concerns over European integration depending on the country; Taylor (2008), for example, suggests that anti-expansion rhetoric was more likely to be found on the political fringes in France in comparison to Great Britain. Less ambiguously, those who report an interest in politics are more likely to report attachment to the European Union.

The regional contextual variables provide the most interesting results from the modelling, and distinguish this study from previous work on attachment that has not 
incorporated a multi-level approach. First, in wealthy regions respondents were significantly less likely to indicate attachment to the local and regional scales and more likely to report attachment to Europe. At the same time, respondents in those regions where GDP is growing were more likely to report attachment to the locality, the region or the nation. This is an interesting finding, which suggests that high levels of economic development result in increased attachment to Europe, while in fastgrowing areas attachment to the locality, region, and nation all remain strong, with these scales serving as a marker of political identity that, potentially, becomes less important as high living standards are consolidated.

Second, respondents residing in regions with lower unemployment rates indicate higher levels of attachment to all four scales under consideration (though the variable is not significant for the national scale). Though this result somewhat contradicts the findings for the individual variable — where those currently not working (including the unemployed, students and pensioners) indicated stronger attachment to Europe alone - the finding potentially indicates that those living in economically vibrant areas are more likely to hold an attachment to a variety of territories.

Lastly, the population density of a respondent's region is only significant for attachment to the locality (at the 0.05 level). There is, perhaps, an expectation that those living in more urbanized areas would indicate a weaker attachment to the local and regional scales, and higher levels of identification with Europe. For the locality the opposite appears to be true, indicating that those living in more densely populated areas view it as an important touchstone to which they desire to maintain some attachment.

\section{Conclusion}


After evaluating Eurobarometer survey data for territorial attachment, it is currently difficult to accept Urry's (2000) prediction for the $21^{\text {st }}$ century-that a new social order of flows would replace the existing social order based on territory. Territorial identities are still relevant, at least in Western Europe. This does not mean that new spaces of flows, mobility and trans-territoriality do not already exist. Based on the above results, it seems plausible though to affirm that these new "spaces of flows" have not substituted the traditional "spaces of place" - to use Castells' (2000) terminology. The link between individuals and territory does not show any sign of losing momentum. Rather than an "either/or" logic, it is perhaps more realistic to think of identity formation in terms of a "both/and" logic, much in the way many Europeans simultaneously evoke their national and European identities.

If territory remains a central dimension in the social articulation of the Self, it is legitimate to ask whether notions of territorial attachment have changed over time. By relying on longitudinal Eurobarometer survey data collected around four scales (local, regional, national, and European), we found no evidence of a territorial re-scaling in the case of Western Europe. Attachment to the nation continues to remain primary, followed closely by local and regional attachments which, throughout the period analyzed, frequently overlap. European attachment has increased over the study period, but, after a phase of instability associated with the introduction of the Euro, has levelled off at $60-70 \%$. Whether European attachment will remain at this level or will change, particularly in time of economic and financial crisis, remains a matter of speculation.

This lack of territorial re-scaling might be interpreted in two ways - either collective identity formation and the processes associated with the post-Fordist transition do not influence each other or the re-scaling is underway, but still to manifest. Alter- 
natively, we can also hypothesize that our instruments are insufficient to capture this phenomenon.

With respect to the factors that explain territorial attachment at multiple scales, a topic largely under investigated by the literature, our statistical model suggests that both personal compositional and regional contextual factors are significant. Geodemographic characteristics (education and age, but also gender and place of residence for particular scales) and personal values and attitudes (the importance of family, willingness to learn a foreign language, and national pride, in particular) are the consistently significant variables throughout the four models. Clearly, it is impossible to identify a single determinant from this class of variables that serves to explain territorial attachment. Instead, such sentiment is the product of a variety of factors, some of which relate to objective features of the individual and some to other personal features, which are commonly held among individuals, regardless of their level of social standing or background.

The regional contextual variables, including GDP growth, GDP per capita, and unemployment, are significant is certain models. For example, respondents living in wealthy regions are more likely to report attachment to Europe, while those in poorer regions are more likely to indicate attachment to the parochial scales: locality and the region. But GDP growth could, in time, erode this attachment to the parochial. Those respondents in regions that have benefited from the post-Fordist economy-with low unemployment rates and high rates of employment in technology jobs-are more likely to indicate attachment to Europe; if the benefits of the post-Fordist economy spread, perhaps this connection to Europe as a territory will grow as well. This is an important finding, which points to the direction that some identity re-scaling might 
indeed be associated with the switch to the new modes of global production - something which our descriptive statistics could not capture.

\section{References}

Agnew J (1987) Place and Politics. Boston: Allen \& Unwin.

Agnew J (1989) The devaluation of place in social science. In: Agnew J and Duncan JS (eds) The Power of Place. Boston: Unwin Hyman, 9-29.

Agnew J (1996) Mapping politics: How context counts in electoral geography. Political Geography 15(2):129-146.

Agnew J (1999). Mapping political power beyond state boundaries. Millennium 28(3): 499-521.

Alliès P (1980) L'invention du Territoire. Grenoble: Presses Universitaires de Grenoble.

Amin A and Thrift N (1995) Territoriality in the global political economy. Nordisk Samhällsgeografisk Tidskrift 20: 3-16.

Ansell CK and Di Palma G (eds) (2004) Restructuring Territoriality. Cambridge: Cambridge University Press.

Antonsich M (2009) On territory, the nation-state and the crisis of the hyphen. Progress in Human Geography 33(6): 789-806.

Antonsich M (2010a) Meanings of place and aspects of the Self. GeoJournal 75: 119132.

Antonsich M (2010b) Exploring the nexus between regional identity and regional governance. European Urban and Regional Studies 17(3): 261-276.

Badie B (1995) La fin des territoires. Paris: Fayard. 
Berezin M and Schain M (eds) (2003). Europe without Borders. Baltimore: Johns Hopkins University Press.

Brenner N (1999) Globalisation as reterritorialisation: The re-scaling of urban governance in the European Union. Urban Studies 36(3): 431-451.

Carey S (2002) Undivided loyalties: Is national identity an obstacle to European integration? European Union Politics 3(4): 387-413.

Castells M (1997) The Power of Identity. Oxford: Blackwell.

Castells M (2000) The Rise of the Network Society. Oxford: Blackwell.

Croucher SL (2004) Globalization and Belonging. Boulder: Rowman \& Littlefield.

Deflem M and Pampel FC (1996) The myth of postnational identity. Social Forces 75(1): 119-143.

Díez Medrano JD and Gutiérrez P. (2001) Nested identities: national and European identity in Spain. Ethnic and Racial Studies 24(5): 753-778.

Duchesne S and Frognier AP (1995) Is there a European identity? In: Niedermayer O and Sinnott R (eds) Public Opinion and International Governance. Oxford: Oxford University Press, 193-226.

Elden S (2010) Land, terrain, territory. Progress in Human Geography 34(6): 799_ 817.

Fitjar RD (2010) Explaining variation in sub-state regional identities in Western Europe. European Journal of Political Research 49(4): 522-544.

Franklin M, Marsh M and McLaren LM (1994) The European question. Journal of Common Market Studies 32(4): 455-472.

Gabel M (1998a) Interests and Integration: Market Liberalization, Public Opinion and European Union. Ann Arbor: University of Michigan Press. 
Gabel M (1998b) Public support for European integration. The Journal of Politics 60(2): 333-354.

Gabel M and Whitten G (1997) Economic conditions, economic perceptions, and public support for European integration. Political Behaviour 19(1): 81-96.

Guéhenno J-M (1995) The End of the Nation-State. Minneapolis: University of Minnesota Press.

Herb G and Kaplan DH (eds) (1999) Nested Identities. Lanham: Rowman \& Littlefield.

Hidalgo MC and Hernandez B (2001) Place attachment. Journal of Environmental Psychology 21(3): 273-281.

Hirst P and Thompson G (1995) Globalization and the future of the nation state. Economy and Society 24(3): 408-442.

Inglehart R (1970) Cognitive mobilization and European identity. Comparative Politics 3(1): 45-70.

Inglehart R (1977) The Silent Revolution. Princeton: Princeton University Press.

Inglehart R, Rabier J-R and Reif K (1991) The evolution of public attitudes toward European integration: 1970-1986. In: Reif K and Inglehart R (eds) Eurobarometer: The Dynamics of European Public Opinion. London: Macmillan.

Janssen JIH (1991) Postmaterialism, cognitive mobilization and public support for European integration. British Journal of Political Science 21(4): 443-468.

Jessop B (1994) Post-Fordism and the state. In: Amin A (ed) Post-Fordism. Oxford: Blackwell, 251-279.

Jessop B (1993). From the Keynesian welfare to the Schumpeterian workfare state. In: Burrows R and Loader B (eds) Towards a Post-Fordist Welfare State? London: Routledge, 13-37. 
Jones M (2001) The rise of the regional state in economic governance: 'Partnerships for prosperity' or new scales of state power? Environment and Planning A 33(7): $1185-1211$.

Keating M (1998) The New Regionalism in Western Europe. Aldershot: Elgar.

Keating M (2009) Social citizenship, solidarity and welfare in regionalized and plurinational states. Citizenship Studies 13(5): 501-513.

Kohli M (2000) The battlegrounds of European identity. European Societies 2(2): 113-137.

Le Galès P (2002) European Cities. Oxford: Oxford University Press.

Lewicka M (2008) Place attachment, place identity, and place memory. Journal of Environmental Psychology 28(3): 209-231.

Low SM and Altman I (1992) Place attachment. New York: Plenum Press.

Marks G (1999) Territorial identities in the European Union. In: Anderson J (ed) Regional Integration and Democracy. Boulder: Rowman \&Littlefield, 69-91.

Mlinar Z (1992) Individualization and globalization. In: Mlinar Z (ed) Globalization and Territorial Identities. Aldershot: Avebury, 15-34.

Nelsen BF and Guth JL (2000) Exploring the gender gap. Women, men and public attitudes toward European integration. European Union Politics 1(3): 267-291.

O' Brien R (1992) Global Financial Integration. London: Pinter.

Ohmae K (1993) The rise of the region state. Foreign Affairs 72: 78-87.

Opp K-D (2005) Decline of the nation state? How the European Union creates national and sub-national identifications. Social Forces 84(2): 653-680.

Paasi A (2009) The resurgence of the 'region' and 'regional identity'. Review of International Studies 35(S1): 121-146.

Pampel FC (2000) Logistic regression. Thousand Oaks: SAGE Publications. 
Poche B (1992) Identification as a process: Territories as an organizational or a symbolic area. In: Mlinar Z (ed) Globalization and Territorial Identities. Aldershot: Avebury, 129-149.

Rokkan S and Urwin DW (1983) Economy, Territory, Identity. London: Sage.

Sassen S (2006) Territory, Authority, Rights. Princeton: Princeton University Press.

Savage M, Bagnall G and Longhurst B (2004) Globalization and Belonging. Thousands Oaks: SAGE.

Scholte JA (1996) The geography of collective identities in a globalizing world. Review of International Political Economy 3(4): 565-607.

Schueth S and O'Loughlin J (2008) Belonging to the world: Cosmopolitanism in geographic contexts. Geoforum 39(2): 926-941.

Swyngedouw E (1997) Excluding the other: The production of scale and scaled politics. In: Lee R and Wills J (eds) Geographies of Economies. London: Arnold, 167-176.

Taylor PG (2008) The End of European Integration: Anti-Europeanism Examined. Abingdon: Routledge.

Taylor PJ (2000) World cities and territorial states under conditions of contemporary globalization. Political Geography 19(1): 5-32.

Tuan Y-F (1976) Humanistic geography. Annals of the Association of American Geographers 66(2): 266-276.

Tunstall H, Rossiter DJ, Pattie CJ, MacAllister I, Johnston RJ and Dorling DFL (2000). Geographical scale, the 'feel-good factor' and voting at the 1997 general election in England and Wales. Transactions of the Institute of British Geographers 25 (1): 51-64. 
Twigger-Ross CL and Uzzell DL (1996) Place and identity process. Journal of Environmental Psychology 16: 205-220.

Urry J (2000) Sociology beyond Societies. London: Routledge.

Williams DR, Patterson ME, Roggenbuck JW and Watson AE (1992). Beyond the commodity metaphor: Examining emotional and symbolic attachment to place. Leisure Sciences 14(1): 29-46.

Yaeger P (ed) (1996) The Geography of Identity. Ann Arbor: The University of Michigan Press.

\section{Appendix 1}

Table 2: Logit model for territorial attachment to the local scale (Odds ratios reported)

\begin{tabular}{|l|l|l|}
\hline Independent variables & Individual variable entry & Fully specified model \\
\hline Geo-demographic & & \\
\hline Males & $0.89^{*}$ & 1.01 \\
\hline Age & $1.19^{* * *}$ & $1.07^{*}$ \\
\hline Education & $0.63^{* * *}$ & $0.71^{* * *}$ \\
\hline Employment status & 0.96 & 1.06 \\
\hline Place of residence & 0.99 & 1.04 \\
\hline $\begin{array}{l}\text { Personal Values and Atti- } \\
\text { tudes }\end{array}$ & & \\
\hline Personal expectation & $0.84^{* * *}$ & \\
\hline Economic expectation & $1.12^{* *}$ & $0.87^{*}$ \\
\hline Importance of family & $1.83^{* * *}$ & $1.16^{* *}$ \\
\hline $\begin{array}{c}\text { Willingness to learn a } \\
\text { foreign language }\end{array}$ & $0.47^{* * *}$ & $1.43^{* * *}$ \\
\hline National pride & $3.22^{* * *}$ & $0.66^{* * *}$ \\
\hline European pride & $1.43^{* * *}$ & $2.63^{* * *}$ \\
\hline Political interest & $0.86^{* * *}$ & 1.07 \\
\hline Political preference & 0.90 & 1.02 \\
\hline Contextual & & 0.95 \\
\hline GDP per capita (PPP) & $0.99^{* * *}$ & \\
\hline GDP growth & $1.19^{* * *}$ & $0.99^{* * *}$ \\
\hline Unemployment rate & $1.05^{* * *}$ & $1.17^{* * *}$ \\
\hline $\begin{array}{c}\text { Employment in high- } \\
\text { tech sectors }\end{array}$ & $0.96^{* * *}$ & $1.04^{* * *}$ \\
\hline Population density & $0.99^{* * *}$ & 1.00 \\
\hline & & $1.00^{*}$ \\
\hline
\end{tabular}




\begin{tabular}{|l|l|l|}
\hline & \\
\hline Observations in model & & 8,449 \\
\hline R-squared & & 0.074 \\
\hline
\end{tabular}

Significance levels are indicated by asterisks: $* \mathrm{p} \leq .05 ; * * \mathrm{p} \leq .01 ; * * * \mathrm{p} \leq .001$

Table 3: Logit model for territorial attachment to the regional scale (Odds ratios reported)

\begin{tabular}{|c|l|l|}
\hline Independent variables & Individual variable entry & Fully specified model \\
\hline Geo-demographic & & \\
\hline Males & 0.90 & 0.92 \\
\hline Age & $1.22^{* * *}$ & $1.11^{* * *}$ \\
\hline Education & $0.64^{* * *}$ & $0.71^{* * * *}$ \\
\hline Employment status & $0.88^{*}$ & 0.92 \\
\hline Place of residence & $0.84^{* * *}$ & 0.88 \\
\hline $\begin{array}{l}\text { Personal Values and Atti- } \\
\text { tudes }\end{array}$ & & \\
\hline Personal expectation & $0.88^{* *}$ & 0.96 \\
\hline Economic expectation & 1.06 & 1.06 \\
\hline Importance of family & $1.92^{* * *}$ & $1.53^{* * *}$ \\
\hline $\begin{array}{c}\text { Willingness to learn a } \\
\text { foreign language }\end{array}$ & $0.52^{* * *}$ & $0.83^{*}$ \\
\hline National pride & $3.56^{* * *}$ & \\
\hline European pride & $1.51^{* * *}$ & $2.64^{* * *}$ \\
\hline Political interest & $0.88^{* *}$ & $1.21^{*}$ \\
\hline Political preference & 0.89 & 1.07 \\
\hline Contextual & & 1.01 \\
\hline GDP per capita (PPP) & $0.99^{* * *}$ & \\
\hline GDP growth & $1.20^{* * *}$ & $0.99^{* * *}$ \\
\hline Unemployment rate & $1.04^{* * *}$ & $1.17^{* * * *}$ \\
\hline $\begin{array}{c}\text { Employment in high- } \\
\text { tech sectors }\end{array}$ & $0.96^{* * *}$ & $1.03^{* *}$ \\
\hline Population density & $0.99^{* * *}$ & 1.01 \\
\hline & & 1.00 \\
\hline Observations in model & & 8440 \\
\hline & & \\
\hline
\end{tabular}




\begin{tabular}{|l|l|l|}
\hline R-squared & 0.074 \\
\hline Signficancelevels are & & \\
\hline
\end{tabular}

Significance levels are indicated by asterisks: $* \mathrm{p} \leq .05 ; * * \mathrm{p} \leq .01 ; * * * \mathrm{p} \leq .001$

Table 4: Logit model for territorial attachment to the national scale (Odds ratios reported)

\begin{tabular}{|l|l|l|}
\hline Independent variables & Individual variable entry & Fully specified model \\
\hline Geo-demographic & & \\
\hline Males & $0.85^{*}$ & $0.83^{*}$ \\
\hline Age & $1.22^{* * *}$ & $1.15^{* * *}$ \\
\hline Education & $0.68^{* * *}$ & $0.81^{* *}$ \\
\hline Employment status & 0.96 & 1.01 \\
\hline Place of residence & $0.89^{* *}$ & 0.96 \\
\hline $\begin{array}{l}\text { Personal Values and Atti- } \\
\text { tudes }\end{array}$ & & \\
\hline Personal expectation & 0.94 & 0.88 \\
\hline Economic expectation & $1.19^{* * *}$ & 1.07 \\
\hline Importance of family & $2.03^{* * *}$ & $1.53^{* * *}$ \\
\hline $\begin{array}{c}\text { Willingness to learn a } \\
\text { foreign language }\end{array}$ & $0.59^{* * *}$ & 0.89 \\
\hline National pride & $9.94^{* * *}$ & \\
\hline European pride & $2.64^{* * *}$ & $7.51^{* * *}$ \\
\hline Political interest & $0.85^{* * *}$ & $1.37^{* * *}$ \\
\hline Political preference & $0.76^{* * *}$ & 1.06 \\
\hline Contextual & & 0.84 \\
\hline GDP per capita (PPP) & $0.99^{* * *}$ & \\
\hline GDP growth & $1.21^{* * *}$ & 0.99 \\
\hline Unemployment rate & 1.01 & $1.13^{* * *}$ \\
\hline $\begin{array}{c}\text { Employment in high- } \\
\text { tech sectors }\end{array}$ & $0.95^{* * *}$ & 1.01 \\
\hline Population density & $0.99^{* * *}$ & 0.99 \\
\hline & & 0.99 \\
\hline Observations in model & & 8446 \\
\hline & & \\
\hline
\end{tabular}


R-squared 0.153

Significance levels are indicated by asterisks: $* \mathrm{p} \leq .05 ; * * \mathrm{p} \leq .01 ; * * * \mathrm{p} \leq .001$

Table 5: Logit model for territorial attachment to the European Union (Odds ratios reported)

\begin{tabular}{|c|c|c|}
\hline Independent variables & Individual variable entry & Fully specified model \\
\hline \multicolumn{3}{|l|}{ Geo-demographic } \\
\hline Males & $1.14 * * *$ & 1.11 \\
\hline Age & $0.97 * *$ & $1.06^{* *}$ \\
\hline Education & $1.27 * * *$ & 1.07 \\
\hline Employment status & 1.01 & $0.86^{*}$ \\
\hline Place of residence & 1.02 & 0.96 \\
\hline \multicolumn{3}{|l|}{$\begin{array}{l}\text { Personal Values and Atti- } \\
\text { tudes }\end{array}$} \\
\hline Personal expectation & $1.29 * * *$ & 0.99 \\
\hline Economic expectation & $1.37 * * *$ & $1.21 * * *$ \\
\hline Importance of family & $1.11^{*}$ & $1.31 * * *$ \\
\hline $\begin{array}{l}\text { Willingness to learn a } \\
\text { foreign language }\end{array}$ & $1.73 * * *$ & $1.33 * * *$ \\
\hline National pride & $1.86^{* * *}$ & $0.62 * * *$ \\
\hline European pride & $9.80 * * *$ & $11.03 * * *$ \\
\hline Political interest & $1.42 * * *$ & $1.31 * * *$ \\
\hline Political preference & 1.01 & 0.98 \\
\hline \multicolumn{3}{|l|}{ Contextual } \\
\hline GDP per capita (PPP) & $1.00 * * *$ & $1.00 * * *$ \\
\hline GDP growth & 0.99 & $0.96^{*}$ \\
\hline Unemployment rate & $1.02 * * *$ & $1.06 * * *$ \\
\hline $\begin{array}{l}\text { Employment in high- } \\
\text { tech sectors }\end{array}$ & 1.00 & 1.01 \\
\hline Population density & 1.00 & 0.99 \\
\hline Observations in model & & 8384 \\
\hline R-squared & & 0.200 \\
\hline
\end{tabular}


Significance levels are indicated by asterisks: * $\mathrm{p} \leq .05 ; * * \mathrm{p} \leq .01 ; * * * \mathrm{p} \leq .001$

Figure 1. Territorial attachment in EU-15 ('very' + 'fairly'), 1991-2007.

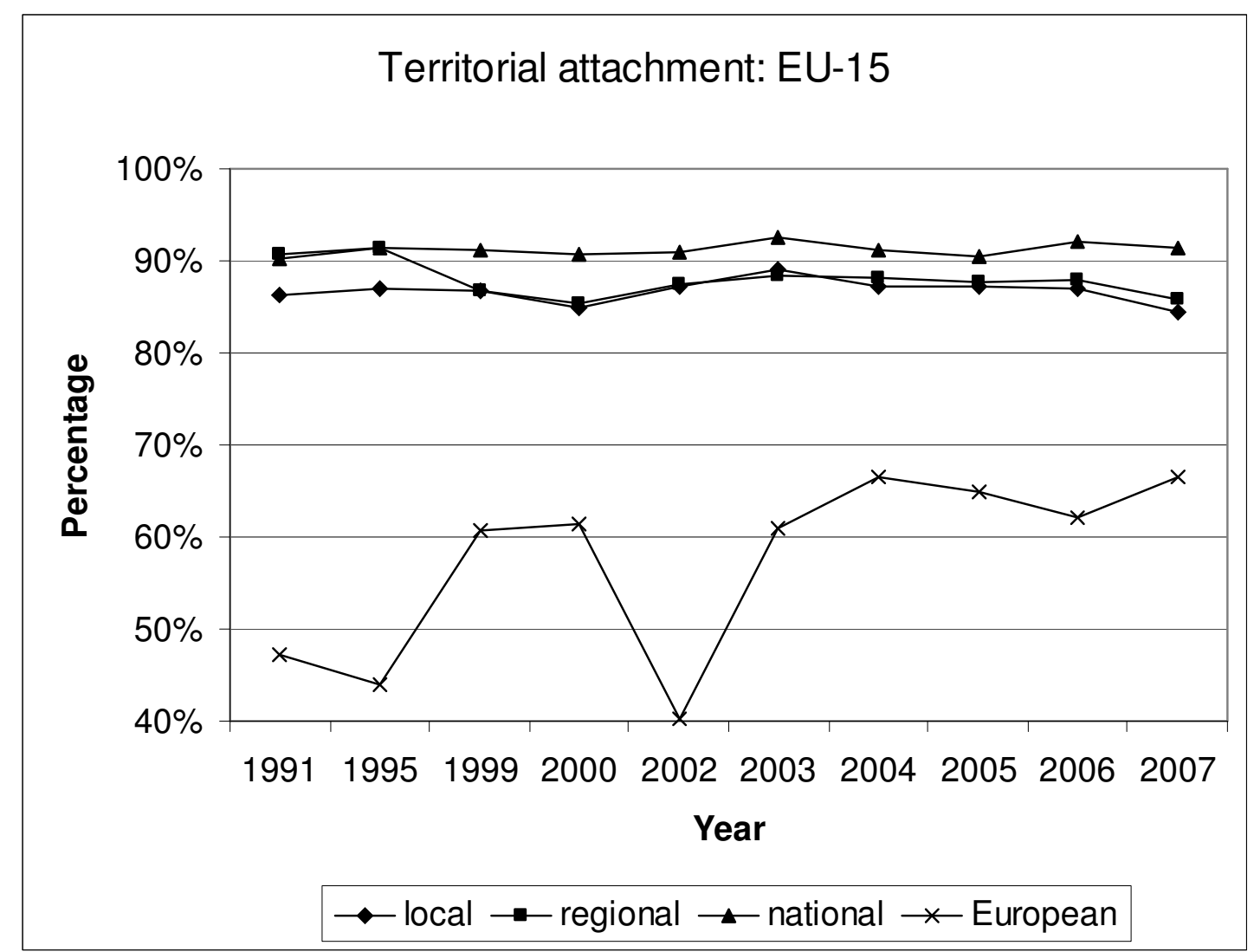

Source: Eurobarometer (1991-2007). 
Figure 2. Geographical belonging ('1st' + '2nd' choice). Aggregated mean values for the following countries: France, Great Britain, Italy, Spain, The Netherlands, Belgium, Denmark, Sweden, and Ireland.

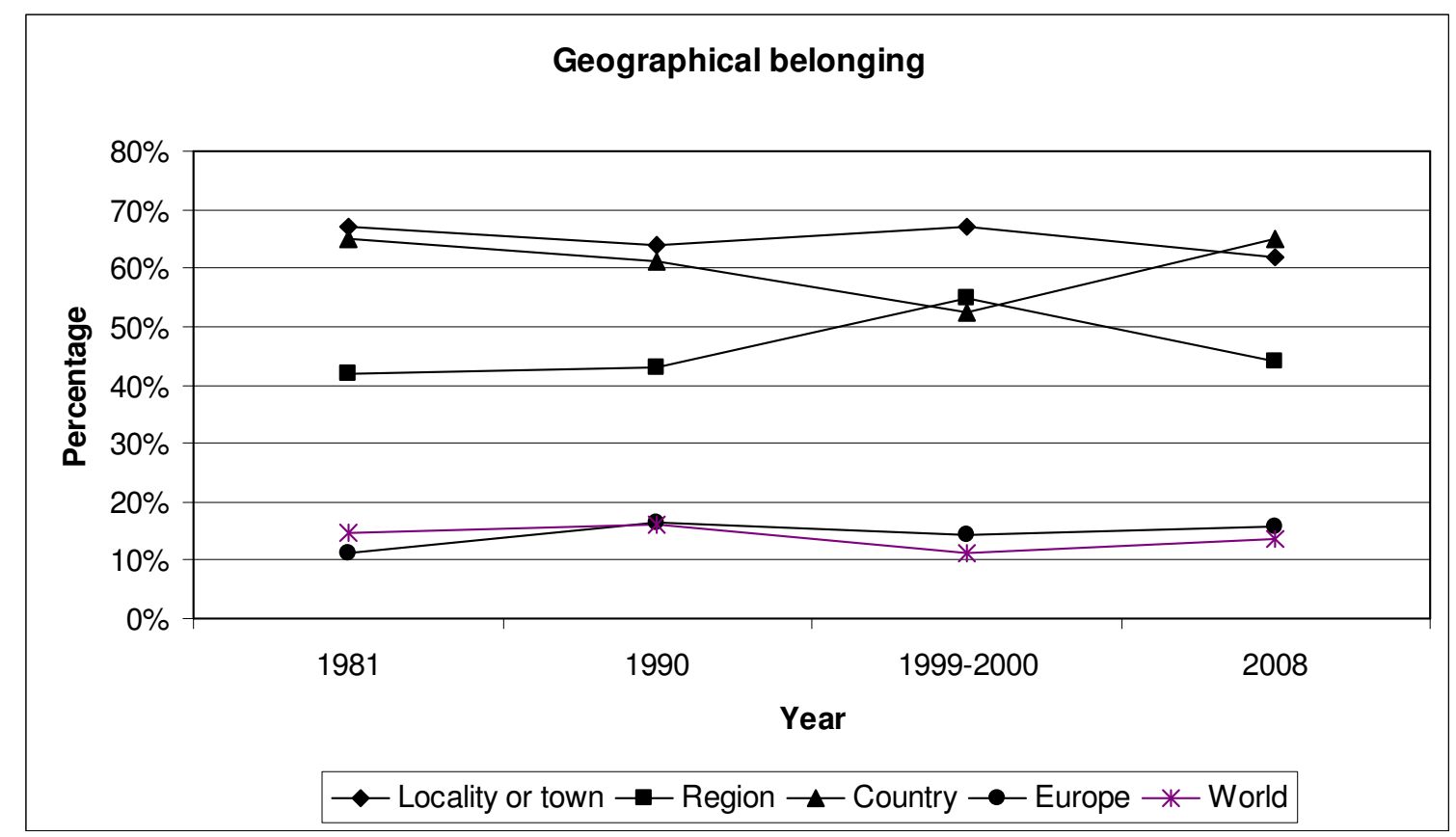

Source: EVS.

Table 1 Correlation coefficients for territorial attachment

\begin{tabular}{|c|c|c|c|c|c|c|}
\hline \multirow{2}{*}{ Local } & \multicolumn{2}{|c|}{ Local } & \multicolumn{2}{c|}{ Regional } & \multicolumn{2}{c|}{ National } \\
\cline { 2 - 7 } & $\mathbf{1 9 9 5}$ & $\mathbf{2 0 0 7}$ & $\mathbf{1 9 9 5}$ & $\mathbf{2 0 0 7}$ & $\mathbf{1 9 9 5}$ & $\mathbf{2 0 0 7}$ \\
\hline Regional & .000 & 1.000 & - & - & - & - \\
\hline National & .601 & .665 & 1.000 & 1.000 & - & - \\
\hline European & .087 & .449 & .396 & .503 & 1.000 & 1.000 \\
\hline
\end{tabular}

Source: Eb 43.1bis (1995); Eb 67.1 (2007)

All values are significant at the 0.01 level ( 2 tailed)

\footnotetext{
${ }^{1}$ Though we considered alternative data sets (European Values Study and International Social Survey Programme), since the primary goal of the present research is to answer a question about the re-scaling of territorial identities, the extensive longitudinal character of a survey series is of fundamental im-
} 
portance. By offering the longest time coverage for the whole region under investigation, Standard Eurobarometer surveys remain therefore the most suitable data sets.

${ }^{2}$ The following Standard Eurobarometer surveys have been used for the present analysis: EB 36 (1991), EB 43.1 bis (1995), EB 51.0 (1999), EB 54.1 (2000), EB 56.3 (2002), EB 60.1 (2003), EB 62.0 (2004), EB 63.4 (2005), EB 65.2 (2006), and EB 67.1 (2007). It should be noted that for EB 36, EB 43.1 bis, and EB 65.2 the question was split in two: "the European Union" and "Europe [as a whole]". In both cases, data about "Europe [as a whole]" were used. In the case of EB 67.1, a fifth item ("attachment to the world") was introduced. Although the first time a question about territorial attachment was asked in Eurobarometer surveys was in 1971 (ECS 71), its different phrasing ("To which of these areas do you feel you belong most strongly? And which next? City/locality, department, region, country, Europe, other") prevents its use in the present study. A similar consideration applies also to EB 50.1 (1998), whose question was formulated in the same way as in the 1971 survey and as such it was not used in the present study. A similar wording issue characterizes also the most recent EB survey available on territorial attachment (EB73.3, 2010), which dropped 'Europe' in favour of 'European Union'. This is the reason why our analysis stops at the year 2007.

${ }^{3}$ Given the cross-national character of the EB survey, it is certainly possible that the same geographical unit might be associated with different meanings in different countries. This might be a potential issue in particular for 'region' - a geographically rather ambiguous term (Antonsich, 2010b) - which, in some cases (e.g. Scotland, Wales, Catalonia, etc.) might be confounded by respondents with 'country'. However, among the possible answers, the EB questionnaire does not list 'our country', but the name of the country of residence of the respondent (e.g., 'Spain', 'France', 'Italy'). This obviously excludes any possible confusion between 'region' and 'country'.

\footnotetext{
${ }^{4}$ We decided to use EB 43.1bis (1995) rather than the oldest Eurobarometer data set available for this series (EB 36 - 1991), since the former includes also Finland, Sweden and Austria.
}

\footnotetext{
${ }^{5}$ As pointed out by one anonymous reviewer, we should acknowledge that positive correlations could also result from subjective differences in how the scale is understood, since attachment means different
} 
things in different contexts. While this is true, it is however difficult to accurately gauge, given the cross-cultural nature of the Eurobarometer survey; instead, we accept the survey as worded and rely on the result as reported.

${ }^{6}$ Among all the Western European countries surveyed by EVS, only eight have been present in all the four waves: France, Great Britain, Italy, Spain, The Netherlands, Belgium, Denmark, Sweden, and Ireland.

${ }^{7}$ The European Communities Study (ECS) administered in 1971 adopted a questionnaire similar to the one used in the EVS, but unfortunately split the regional answer in two categories ('department' and 'province') making difficult to compare the data.

${ }^{8}$ The focus on EB 60.1 rather than on more recent Eurobarometer data sets is due to the fact that at the time this study was carried out Eurostat data for European regions were not yet available for more recent years. Eurostat statistical data can be retrieved free of charge from their official website: http://ec.europa.eu/eurostat.

${ }^{9}$ NUTS (Nomenclature of Territorial Units for Statistics) are the statistical units used by Eurostat, the official statistical institute of the European Union. NUTS are classified into 3 levels. In general, level 1 corresponds to provinces or counties, level 2 to administrative regions and level 3 to macro-regions within each member-state of the EU. NUTS 2 correspond to the geographical scale at which Eurobarometer survey data were collected.

${ }^{10}$ In these two cases, to use data for the year 2003 only is not inconsistent in relation to the other geographical contextual variables - for which the average over the years 2001-2003 was used. It seems in fact legitimate to assume that both population density and higher education percentage are more stable over time than economic and labour data.

${ }^{11}$ Inglehart's theory about changing political attitudes in Western Europe revolves around two major concepts: post-materialism (giving priority to symbolic, as opposed to material, objects) and cognitive 
mobilization (the capacity for processing information at certain levels of abstraction). However, more recent quantitative studies have suggested that both post-materialism (Janssen 1991) and cognitive mobilization (Gabel 1998a) do not play a significant role in influencing public support for the European Union.

${ }^{12}$ Again, we are indebted to an anonymous reviewer for this second suggestion. 